Cakrawala Dini: Jurnal Pendidikan Anak Usia Dini | p-ISSN 2087-1317 | e-ISSN 2621-8321

Vol. II. No.I Mei 2020 | Hal 17-22

\title{
PENGARUH PEMBELAJARAN TARI KREATIF TERHADAP KECERDASAN NATURALIS ANAK USIA 5-6 TAHUN
}

\author{
Jojor Renta Maranatha ${ }^{1}$, Hayani Wulandari ${ }^{2}$, Windy Chyndiana ${ }^{3}$ \\ ${ }^{1,2,3}$ Universitas Pendidikan Indonesia Kampus Purwakarta
}

\begin{abstract}
The purpose of this study is to determine the effect of creative dance learning on naturalist intelligence children age 5-6 years. This research is a quasi-experimental study with a pretest-posttest control group design, with two groups that are the experimental group given creative dance learning and the control group conventional learning. The research results obtained from the paired sample tset test were obtained the Sig (2-tailed) value of 0,000 <0.05, the meaning Ho was rejected. Then it can be concluded that there is an effect of creative dance learning on natural intelligence of children aged 5-6 years.
\end{abstract}

Keywords: Naturalist intelligence, creative dance, 5-6 years old children

\begin{abstract}
Abstrak: Tujuan penelitian ini adalah untuk mengetahui pengaruh pembelajaran tari kreatif terhadap kecerdasan naturalis anak usia 5-6 tahun. Penelitian ini merupakan penelitian kuasi eksperimen dengan desain penelitian pretest-posttest control group design, dengan dua grup yaitu grup ekperimen yang diberikan pembelajaran tari kreatif dan grup kontrol yang tidak diberikan treatment atau dengan pembelajaran konvensional. Hasil penelitian diperoleh dari uji paired sample tset didapatkan hasil nilai Sig (2-tailed) $0,000<0,05$, artinya Ho ditolak. Maka, dapat disimpulkan terdapat pengaruh pembelajaran tari kreatif terhadap kecerdasan naturalis anak usia 5-6 tahun.
\end{abstract}

Kata Kunci : Kecerdasan Naturalis, tari kreatif, anak usia 5-6 tahun

\footnotetext{
${ }^{1}$ Universitas Pendidikan Indanesia, Email: jojor.renta国upi.edu

2 Universitas Pendidikan Indanesia, Email: hayaniwulandari国upi.edu

${ }^{3}$ Universitas Pendidikan Indanesia, Email: windychyndiana回student.upi.edu
} 


\section{PENDAHULUAN}

Masa anak usia dini lebih mengarah pada masa pengenalan terhadap berbagai informasi baik pada perkembangan kognitif, afektif maupun psikomotornya. Sejalan dengan teori Benjamin S. Bloom seorang tokoh psikologi pendidikan dari Amerika Serikat, yang merumuskan bahwa ada tiga elemen pokok dalam pendidikan yaitu aspek kognitif, afektif dan psikomotor. (Sujiono, 2010) Aspek kognitif meliputi kemampuan peserta didik lebih menekankan pada aspek intelektual, seperti pengetahuan, serta keterampilan berpikir anak. Aspek afektif dikaitkan dengan aspek perasaan dan emosi, seperti minat, sikap, apresiasi dan cara penyesuaina diri. Sedangkan aspek psikomotor lebih menekankan pada aspek fisik motorik seperti menulis, menari, berenang, berlari dan sebagainya.

Perkembangan tersebut dapat dilihat dari berbagai intellegence yang dimiliki oleh anak usia dini. Setiap anak mampu mengeksplorasi dunianya dan memecahkan masalah yang dihadapinya. Berbagai kecerdasan yang dimiliki oleh masing-masing anak ini dapat menjadi modal utama dalam pembelajarannya dimasa yang akan datang.

Namun pada kenyataan saat ini dalam konteks pembelajaran di PAUD masih terdapat pembelajaran yang konvensional dan terpusat pada guru. Guru lebih aktif daripada anak, sehingga anak tidak diberi kesempatan untuk mengemukakan ide, gagasan serta konsep pemikirannya. Selain itu, pengenalan lingkungan baik di dalam maupun di luar belum diberikan secara maksimal. Berdasarkan hasil observasi menunjukkan bahwa masih ditemukan guru yang masih belum memanfaatkan lingkungan sekitar, baik hewan, tumbuhan, serta fenomena-fenomena alam yang terjadi di lingkungan sekitar sekolah untuk dijadikan sebagai bagian dari pembelajaran anak usia dini. Dari faktor tersebut menyebabkan lemahnya anak dalam mengemukakan pendapat, ide, gagasan, berfikir kreatif serta anak belum menunjukan bakat kecerdasan alamnya dengan baik. Maka dari itu guru dapat mengembangkan potensi anak melalui berbagai strategi dan pendekatan pembelajaran yang menyenangkan bagi anak.

Kecerdasan naturalis merupakan kecerdasan yang mengacu pada kepekaan anak terhadap alam dan lingkungan (Armstrong, 2004). Orang yang memiliki tingkat kecerdasan naturalis yang tinggi amat sadar akan bagaimana membedakan tanaman, hewan, pegunungan, atau konfigurasi awan yang berbeda dalam bentuk ekologis mereka.

Pendapat di atas dapat dijelaskan bahwa kecerdasan naturalis merupakan kemampuan untuk mengenal alam seperti flora, fauna, serta fenomena alam lainnya. Alam dapat diamati di rasakan sehingga dapat memenuhi pengembangan kecerdasan serta memberikan pengalaman nyata bagi anak.

Dunia anak adalah dunia bermain bahkan prinsip pembelajaran di Taman Kanak-Kanak yaitu 'bermain sambil belajar atau belajar sambil bermain". Sehingga untuk memberikan pembelajaran yang tepat untuk anak usia dini yaitu salah satunya dengan melalui seni tari, dengan menari anak diberi kesempatan untuk berekspresi, bereksplorasi dan berimajinasi.

Tari merupakan bagian dari seni yang melibatkan gerak tubuh manusia, tubuh merupakan alat utama dan gerak tubuh menjadi media untuk mengekspresikan. Di dalam tari terdapat tiga unsur tari diantaranya yaitu ruang, waktu, dan tenaga.

Tenaga adalah kekuatan yang mendorong terjadinya gerak. Jenis tenaga diantaranya berat/ringan, kuat/lemah. Hal tersebut merupakan kunci utama bagi penari yang harus dikuasai oleh penari sehingga dapat menghasilkan gerakan yang kreatif dan gerakan yang indah. Ruang adalah tempat untuk bergerak 
yang bersifat harfiah, contohnya panggung terbuka, panggung tertutup. Sifat imajinatif tercipta karena bendabenda di panggung dan karena gerakan penari, arah gerak penari, tinggi rendah penari pada waktu menari. Selain itu, tari menurut (Joice, 1973) merupakan tingkat ruang tubuh (tinggi, rendah), fokus (arah pandangan), jalur (melengkung, lurus), arah (maju, mundur).

Waktu merupakan tempo yang diperlukan penari untuk melakukan suatu gerakan, lamanya waktu tergantung dari cepat lambatnya (tempo) penari dalam melakukan gerakan, panjang pendeknya ketukan (ritme) penari dalam bergerak dan lamanya (durasi) melakukan gerakan.

Masunah menjelaskan bahwa aspek psikomotor dapat dicapai melalui kegiatan anak bergerak dalam upaya mengekspresikan imajinasi kreatifnya melalui tubuhnya (Yulianti, 2016). Hal ini merupakan hasil pemikiran tentang kemungkinan gerak tubuh atau perumpamaan, tanpa pengolahan pikir tidak akan terwujud sebuah gerakan.

Pernyataan di atas menyatakan bahwa pada saat menari anak sedang mengolah imajinasi dan menghasilkan kreativitas. Kreativitas tersebut hasil dari olah pikir, ide dan gagasan anak yang ditampakkan melalui gerak tubuhnya. Konsep tari kreatif yang akan digunakan yaitu konsep tari dari (Joice, 1973), yang merupakan tokoh tari kreatif yang membahas mengenai proses tari yang di dalam terdapat kreativitas.

Joice (1973) menjelaskan bahwa tari kreatif melibatkan pikiran, tubuh, dan jiwa untuk mengekspresikan suatu gerakan berdasarkan ide, pengalaman serta kreativitas masing-masing anak. Dalam menari konsentrasi dan kesadaran anak hanya terpaku pada tindakan gerakan, sehingga gerakan tari yang dihasilkan anak akan berbeda satu dengan lainnya. Guru memberikan stimulasi sesuai dengan yang akan dilakukan, salah satunya mengenai lingkungan.

\section{METODOLOGI PENELITIAN}

Metode penelitian yang digunakan dalam penelitian ini adalah penelitian kuasi eksperimen, dengan desain penelitian pretest-posttes control group design. Penelitian ini menggunakan dua grup, yaitu grup eksperimen dan grup kontrol. Grup eksperimen diberikan pembelajaran tari kreatif, dan grup kontrol dengan pembelajaran konvensional.

Tabel 1. Desain penelitian pretest-posttest control group design

\begin{tabular}{|l|c|c|c|}
\hline Kelompok & $\begin{array}{c}\text { Pre- } \\
\text { Test }\end{array}$ & Tindakan & $\begin{array}{c}\text { Post- } \\
\text { Test }\end{array}$ \\
\hline Eksperimen & $\mathrm{O} 1$ & $\mathrm{X}$ & $\mathrm{O} 2$ \\
\hline Kontrol & $\mathrm{O} 3$ & & $\mathrm{O} 4$ \\
\hline
\end{tabular}

Keterangan:

O1 : Pre-test kelas eksperimen

O2 : Post-test kelas eksperimen

O3 : Pre-test kelas kontrol

O4 : Pre-test kelas kontrol

$\mathrm{X}$ : Tari Kreatif

Partisipan yang terlibat pada penelitian ini adalah anak Taman Kanakkanak salah satu TK di Purwakarta kelas B dengan rentang usia 5-6 tahun. Kelas B1 sebagai kelas eksperimen, dan kelas B2 sebagai kelas kontrol.

Instrumen pengumpulan data dalam penelitian ini adalah rating scale kecerdasan naturalis. Rating scale kecerdasan naturalis digunakan dalam pretest-posttes pada kelas ekperimen dan kelas kontrol.

Sebelum analisis dilakukan, terlebih dahulu dilakukan uji normalitas dan uji homogenitas. Uji normalitas data dilakukan dengan uji Shapiro-Wilk, sedangkan uji homogenitas dilakukan dengan uji Levene. Untuk mengefisiensikan waktu, maka perhitungan uji normalitas dan homogenitas dilakukan dengan bantuan program SPSS 22. 
HASIL PENELITIAN

DAN

\section{PEMBAHASAN}

Berdasarkan uji normalitas data pretest grup eksperimen dan kontrol, maka diperoleh bahwa data pretest grup eksperimen dan grup kontrol adalah normal, seperti tertara pada table di bawah ini.

Tabel 2. Pengujian normalitas data pretest grup ekperimen dan pretest grup kontrol.

\begin{tabular}{|c|c|c|}
\hline & $\begin{array}{c}\text { Shapiro-Wilk } \\
\text { Sig. }\end{array}$ & Keterangan \\
\hline $\begin{array}{c}\text { Postest } \\
\text { Eksperimen }\end{array}$ &, 707 & $\begin{array}{c}\text { Data Berdistribusi } \\
\text { Normal }\end{array}$ \\
\hline $\begin{array}{c}\text { Postest } \\
\text { Kontrol }\end{array}$ &, $\mathbf{0 8 8}$ & $\begin{array}{c}\text { Data Berdistribusi } \\
\text { Normal }\end{array}$ \\
\hline
\end{tabular}

Berdasarkan uji homogenitas data pretest grup eksperimen dan grup kontrol, maka diperoleh bahwa data pretest grup eksperimen dan grup kontrol adalah normal, seperti tertera pada tabel di bawah ini.

Tebel 3. Pengujian homogenitas data pretest grup eksperimen dan pretest grup kontrol.

\begin{tabular}{|c|c|c|}
\hline Levene Statistic & Sig. & Keterangan \\
\hline 3,476 &, 074 & $\begin{array}{c}\text { Data dinyatakan } \\
\text { Homogen }\end{array}$ \\
\hline
\end{tabular}

Berdasarkan uji normalitas data posttest grup eksperimen dan kontrol, maka diperoleh bahwa data posttest grup eksperimen dan grup kontrol adalah normal, seperti tertara pada tabel di bawah ini.

Tabel 4. Pengujian normalitas data posttest grup ekperimen dan posttest grup kontrol.

\begin{tabular}{|c|c|c|}
\hline & Shapiro-Wilk & \multirow{2}{*}{ Keterangan } \\
\hline & Sig & \\
\hline $\begin{array}{c}\text { Postest } \\
\text { Eksperimen }\end{array}$ & ,768 & $\begin{array}{c}\text { Data berdistribusi } \\
\text { Normal }\end{array}$ \\
\hline $\begin{array}{l}\text { Postest } \\
\text { Kontrol }\end{array}$ & ,318 & $\begin{array}{c}\text { Data berdistribusi } \\
\text { Normal }\end{array}$ \\
\hline
\end{tabular}

Berdasarkan uji homogenitas data posttest grup eksperimen dan grup kontrol, maka diperoleh bahwa data posttest grup eksperimen dan grup kontrol adalah normal, seperti tertera pada tabel dibawah ini.

Tebel 5. Pengujian homogenitas data posttest grup eksperimen dan posttest grup kontrol.

\begin{tabular}{|l|c|c|}
\hline $\begin{array}{c}\text { Levene } \\
\text { Statistic }\end{array}$ & Sig. & \multicolumn{1}{|c|}{ Keterangan } \\
\hline 3,423 &, 076 & $\begin{array}{l}\text { Nilai sig (2-tailed) > 0,05 maka } \\
\text { H0 diterima (Data mempunyai } \\
\text { varians yang homogen) }\end{array}$ \\
\hline
\end{tabular}

Berdasarkan hasil yang diperoleh dengan menggunakan bantuan software SPSS 22 melalui teknik paired samples test didapatkan nilai Sig (2-tailed) 0,000 $<0,05$ artinya HO ditolak, jadi disimpulkan terdapat pengaruh pembelajaran tari kreatif terhadap kecerdasan naturalis anak usia 5-6 tahun.

Untuk mengetahui besarnya efek pembelajaran tari kreatif terhadap kecerdasan naturalis, maka digunakan perhitungan regresi linear sederhana. Melalui hasil perhitungan dengan menggunakan program SPSS 22, maka diperoleh nilai R Square sebesar 0,749. Hal tersebut menunjukan bahwa pengaruh pembelajaran tari kreatif pada kecerdasan naturalis anak usia 5-6 thn sebesar $74,9 \%$ sedangkan $25,1 \%$ tari kreatif dipengaruhi oleh variabel yang tidak diteliti, jadi pembelajaran tari kreatif memperngaruhi kecerdasan naturalis anak sebesar $74,9 \%$.

Untuk mengetahui kecerdasan naturalis mana yang lebih baik antara grup eksperimen dan kontrol, dilakukan perhitungan pretest kontrol dengan pretest eksperimen, dengan menggunakan uji T. Berdasarkan hasil perhitungan uji T tersebut, diperoleh nilai 0,996. Kemudian dilanjutkan dengan pengujian posttest eksperimen dan posttest kontrol, yang juga dilakukan dengan uji T. Berdasarkan hasil perhitungan uji $\mathrm{T}$ posttest grup eksperimen dan grup kontrol, diperoleh 
nilai Sig < 0,05 yaitu 0,015 . Berdasarkan hasil uji $\mathrm{T}$ tersebut, diketahui bahwa $0,015<0,05$; maka H0 ditolak. Jadi dapat disimpulkan kecerdasan naturalis anak usia 5-6 tahun yang mendapatkan pembelajaran tari kreatif lebih baik dibandingkan kecerdasan naturalis anak usia 5-6 tahun yang mendapatkan pembelajaran konvensional.

Materi pembelajaran tari kreatif yang dirancang dari perlakuan satu sampai empat pada kelas eksperimen merupakan upaya untuk mengembangkan kecerdasan naturalis anak. Metode yang digunakan dalam pembelajaran tari kreatif yaitu demonstrasi. Sebagaimana yang dijelaskan oleh (Mulyani, 2017), bahwa metode demonstrasi ini cocok dipakai dalam mengajarkan sebuah materi; terutama materi tari, karena guru akan mengalami kesusahan jika hanya menjelaskan secara lisan saja.

Dalam hal ini guru menunjukkan, mengerjakan, dan menjelaskan apa yang sedang dilakukannya (showing, doing, and telling). Tiga hal tersebut merupakan komponen utama dalam metode demonstrasi. Makna demonstrasi bagi anak ialah dapat memperlihatkan secara konkret apa yang dilakukan atau mengkomunikasikan gagasan, konsep, ide dengan peragaan serta mengembangkan kemampuan mengamati secara teliti dan cermat.

Dari perlakuan pembelajaran tari kreatif yang diberikan oleh peneliti, anak-anak secara terus menerus mengalami perkembangan yang signifikan. Anak-anak mulai terlihat jelas kecerdasan naturalis karena pada setiap perlakuan anak-anak mampu mengekspresikan gerakan yang maksimal serta mampu mengungkapkan secara verbal. Hal tersebut diperkuat oleh pernyataan (Joice, 1973) bahwa mereka melihat unsur-unsur tarian dan menemukan bahwa mereka dapat berhubungan dan berkomunikasi tentang apa yang mereka lihat, dengar dan rasakan serta mereka dapat berbicara "bahasa tubuh" dan dapat membacanya dalam bahasa lain.

Pada kelas eksperimen peneliti memberikan stimulus dengan pembelajaran tari kreatif berupa sintaksintak tari kreatif, anak-anak menciptakan gerakan sesuai dengan imajinasi dan kreativitasnya, sehingga menghasilkan gerakan yang berbeda. Sejalan dengan pendapat (Mulyani, 2017), pada setiap gerakan harus memiliki tiga unsur tari yaitu yang pertama adalah tenaga yang merupakan kekuatan yang mengawali, mengendalikan, dan mengehentikan gerak. Perubahan-perubahan yang terjadi oleh penggunaan tenaga yang berbeda dalam gerak tari, akan membangkitkan atau mempengaruhi penghayatan terhadap tarian.

Pada saat peneliti memberi stimulus dengan gerakan cepat anakanak menggerakan dengan gerakan yang sesuai dengan tempo. Anak-anak terlihat sangat semangat ketika menciptakan gerak sehingga menimbulkan tenaga yang berbeda sesuai dengan karakteristiknya masing-masing.

Kemudian unsur yang kedua yaitu ruang, dalam tari ruang adalah salah satu unsur pokok yang menentukan terwujudnya suatu gerak. Hal ini karena gerak yang dibuat memiliki desain ruangan dan berhubungan dengan bendabenda lain dalam dimensi ruang dan waktu. Pada penelitian ini, setiap anak menggerakan dengan ruang yang berbeda, hal ini sesuai dengan unsur tari yaitu ruang merupakan salah satu unsur pokok yang menentukan terwujudnya suatu gerak.

Ketiga yaitu waktu merupakan elemen yang membentuk gerak tari selain unsur tenaga dan ruang. Unsur waktu ini tidak dapat dipisahkan satu dengan lainnya. Hal ini karena satu struktur yang saling berhubungan, hanya perannya saja yang berbeda. 


\section{KESIMPULAN}

Terdapat pengaruh pembelajaran tari kreatif bagi kecerdasan naturalis anak usia 5-6 tahun, di lihat dari hasil uji SPSS 22 melalui teknik paired samples test di dapatkan hasil nilai Sig (2-tailed) 0,000 < 0,05 . Artinya $\mathrm{H} 1$ diterima sehingga terdapat pengaruh pembelajaran tari kreatif pada jenjang umur 5-6 tahun.

Besarnya pengaruh pembelajaran tari kreatif terhadap kecerdasan naturalis diperoleh melalui hasil nilai $\mathrm{R}$ square sebesar 0,749 . Artinya bahwa pengaruh pembelajaran tari kreatif sebesar 74,9\% sedangkan $25,1 \%$ tari kreatif diipengaruhi variabel luar.

Kecerdasan naturalis anak usia 5-6 tahun yang mendapatkan pembelajaran tari kreatif lebih baik, bila dibandingkan kecerdasan naturalis anak usia 5-6 tahun yang mendapatkan pembelajaran tari konvensional. Hal ini dibuktikan oleh pengujian postest grup eksperimen dan postest grup kontrol yang menghasilkan nilai $\mathrm{Sig}<0,05$, maka $\mathrm{H}_{0}$ ditolak. Artinya bahwa kecerdasan naturalis anak usia 5-6 tahun yang mendapatkan pembelajaran tari kreatif lebih baik dibandingkan kecerdasan naturalis anak usia 5-6 tahun yang mendapatkan pembelajaran konvensional.

\section{DAFTAR PUSTAKA}

Armstrong, T. (2004). Menerapkan Multiple Intelligences di Sekolah. Bandung: PT Mizan Pustaka.

Joice, M. (1973). First Steps in Teaching Creative Dance to Children. Toronto.

Mulyani, N. (2017). Pengembangan Seni Anak Usia Dini. Bandung: PT Remaja.

Sujiono, d. S. (2013). Bermain Kreatif Berbasis Kecerdasan Jamak. Jakarta: PT. Indeks.

Sujiono, N. S. (2010). Bermain Kreatif Berbasis Kecerdasan Jamak. Jakarta : PT Indeks.

Yulianti, R. (2016). Pembelajaran Tari Kreatif Untuk Meningkatkan
Pemahaman Cinta Lingkungan Pada Anak Usia Dini. Jurnal Pendidikan dan Kajian Tari, 04. 